\title{
Pääkirjoitus
}

\section{Puheen ja vuorovaikutuksen puolesta}

Prologin tehtävänä on sen perustamisesta lähtien ollut tarjota suomenkielinen ikkuna tuoreeseen puheviestinnän alan tutkimukseen Suomessa. Tämä on edelleen äärimmäisen tärkeä tavoite. Toki on niin, että tiedejulkaisemisen maailma ja akateemisen työn realiteetit ovat jossakin määrin muuttuneet Prologin yli kymmenvuotisen taipaleen aikana. Muun muassa keskustelu englanninkielisen julkaisemisen mahdollistamisesta Prologin sivuilla on tullut mukaan aikaisempaa varteenotettavampana vaihtoehtona. Suomeksi tai ruotsiksi julkaisevat kotimaiset tiedekustantajat joutuvat painimaan kielikysymyksen kanssa aikaisempaa useammin - tähän suuntaan vie esimerkiksi Julkaisufoorumi-luokitus, jossa suomenkielisen julkaisun on vaikeaa tai lähes mahdotonta saada korkeaa luokitusta.

Olen keskustellut tästä kielikysymyksestä useiden Prologos ry:n jäsenten ja muiden suomalaisten tieteenharjoittajien kanssa, eikä mitään yhtenäistä linjaa näytä näiden keskustelujen pohjalta syntyvän. Sinänsä on totta, että esimerkiksi suomalaisissa yliopistossa tehtävistä väitöksistä yhä useampi on pelkästään englanninkielinen väitöstilaisuutta myöten, ja että 2010-luvun akateemisen maailman lingua francaa ei voida jättää huomiotta, kun suunnitellaan Prologin kaltaisten julkaisujen tulevaisuutta. Toisaalta näen itse hyvin vahvasti, että englanninkielisiä julkaisukanavia on maailmalla runsaasti siinä missä suomeksi tuotetusta tieteellisestä sisällöstä on alallamme jatkuva pula. Me yksinkertaisesti tarvitsemme suomenkielistä foorumia, jossa kehittää ja haastaa käsitteitä ja teorioita omalla kielellämme.

Ajat kuitenkin muuttuvat, eikä mitään päätöstä kannata hakata kiveen. Esimerkiksi pitkäikäinen ja arvostettu Sosiologia-lehti julkaisee loppuvuodesta 2015 ensimmäisen englanninkielisen numeronsa, ja tässä Prologissa yksi lectio praecursorioista on englanniksi. Anomalioita vai heikkoja signaaleja tulevasta, ken tietää? Joka tapauksessa haluan tässä omalta osaltani muistuttaa, että Prologos ry ja sitä myöten myös Prologi eivät syyttä suotta liittyneet pari vuotta sitten Tieteen kieli - Vetenskapets språk -hankkeeseen. Kotimainen ja kotimaisilla kielillä tapahtuva julkaiseminen on edelleen meidän näkökulmastamme itseisarvo. 
Järjestyksessään yhdestoista puheviestinnän vuosikirja tarjoaa monitahoisen foorumin uuden vuorovaikutustutkimuksen esittelemiselle. Joitakin vuosia sitten silloinen vuosikirjan päätoimittaja Maarit Valo puhui siitä, että Prologin tulevaisuuden ei voida nähdä rakentuvan yksin pienehkön puheviestintä-tieteenalan varaan. Haasteena on tällöin ainakin tunnettuuden kasvattaminen sekä toisaalta myös fokuksen säilyttäminen. Näkisin, että näissä tavoitteissa ollaan onnistuttu hyvin, vaikka paljon työtäkin on vielä edessä.

Kun tarkastelen arviointiprosessin läpi kulkeneita ja lopulliseen julkaisuun päätyneitä artikkeleita, huomaan, että Vuoden 2015 puheviestinnän vuosikirjan kantavia teemoja ovat haastavista aiheista puhuminen sekä vuorovaikutus työelämän eri konteksteissa. Kuten tiedetään, vuorovaikutuksen prosessit sekä niihin liitetyt merkityksenannot voivat liittyä monin tavoin niin hyvin- kuin pahoinvoinninkin kokemuksiin. Vuorovaikutus ei tietenkään ole aina helppoa tai ongelmatonta, ja usein juuri nämä niin kutsutut kipupisteet tarjoavat hedelmällisen lähtökohdan tutkimukselle.

Johanna Ruonalan ja Sanna Herkaman artikkeli tarkastelee naisten käsityksiä ja kokemuksia seksuaaliviestinnästä. Ajatukset siitä, millaista keskustelua seksuaaliasioista kaivataan ja millaiset aiheet koetaan haastavaksi, havainnollistavat yksityisyyden suojelemisen ja itsestäkertomisen välistä jännitettä.

Marjanna Artkosken ja Marja-Leena Hyvärisen tutkimuksessa kuvataan lääkäreiden kokemuksia huonojen uutisten kertomisesta potilaille sekä heidän valitsemiaan toimintatapoja näissä emotionaalisesti kuormittavissa vuorovaikutustilanteissa. Esimerkiksi viestinnän suoruus ja asiapainotteisuus voivat olla samalla keinoja suojautua tunnekuormalta, joka aiheutuu huonojen uutisten kertomisesta.

Eveliina Pennanen tarkastelee kirjoituksessaan sairaalan hoitohenkilöstön käsityksiä työyhteisön vuorovaikutuksen merkityksestä työhyvinvoinnille. Tutkimus nostaa esiin tulkinnan moniulotteisuuden ja yksilökohtaisuuden. Positiivisestikin latautuneet käsitteet, kuten kuuluminen työyhteisöön ja vaikuttaminen sen toimintaan, voidaan tulkita toisella tavoin kuin mitä koulutusmateriaalit tai intuitio antaisivat ymmärtää. Herkkyys näiden tulkintojen monitahoisuudelle onkin tärkeää sekä tutkijan että esimerkiksi kouluttajan tai lähijohtajan näkökulmasta.

Piia Mikkolan tutkimuksessa pureudutaan esimiehen ja alaisen välisiin kehityskeskusteluihin keskustelunanalyysin avulla. Tutkimuksessa nostetaan esiin kehityskeskustelulomakkeiden rooli vuorovaikutuksen resurssina ja jäsentäjänä. Ei-inhimillisten toimijoiden osuus vuorovaikutuksessa onkin kiinnostava ja usein liian vähälle huomiolle jäävä näkökulma. 
Yksinkertaiseltakin vaikuttava väline, kuten tässä kehityskeskustelulomake, voi avata yllättäviä osallistumisen ja vaikuttamisen mahdollisuuksia vuorovaikutuksen osapuolille.

Mitra Raappanan ja Maarit Valon artikkeli avaa työelämän hajautettujen tiimien rakenteistumista vuorovaikutustehtävien näkökulmasta. Kokoustilanteiden vuorovaikutuksen analyysi piirtää monipuolisen kuvan tiimien mahdollisista vuorovaikutustehtävätyypeistä. Tuloksissa käy kiinnostavalla tavalla ilmi se, että teknologialla tai niin kutsutulla virtuaalisuudella ei välttämättä ole määräävää merkitystä suhteessa muihin tiimin vuorovaikutuksessaan neuvottelemiin tehtäviin.

Mirjami Ikonen käsittelee tutkimuksessaan esimies-alaissuhteen luottamusta vuorovaikutuksessa rakentuvana ilmiönä. Erityisen kiinnostava oli havainto sinänsä pienten väärinkäsitysten, esimerkiksi tahattomina pidettyjen reagoimatta jättämisten, potentiaalisesta merkityksestä vuorovaikutussuhteelle. Artikkelissa käsitellyn kaltainen luottamus rakentuu pitkäjänteisesti, pienin teoin, jokapäiväisessä vuorovaikutuksessa. Avainasemaan nousee tällöin herkkyys ja arvostuksen sekä armon osoittaminen vuorovaikutuskumppania kohtaan.

Nyt julkaistavista tutkimusartikkeleista huomaa konkreettisesti, kuinka vahva rooli työyhteisöjen vuorovaikutuksen sekä siihen liitettyjen merkitysten tutkimuksella on puheviestintätieteissä ja sen lähitieteenaloilla. Artikkeleista näkee myös - jälleen kerran - kuinka vuorovaikutuksen tutkimuksen tarjoamaa ymmärrystä on usein verrattain helppo soveltaa käytännön toimintaan.

Perinteiseen tapaan tässä Prologissa julkaistaan myös neljä lectio praecursoriaa. Niiden kirjoittajat ovat väitelleet puheviestinnän alalta vuoden 2014 Prologin julkaisemisen jälkeen. Kaiken kaikkiaan voidaan sanoa, että vuosi 2015 on ollut sekä puheviestinnän kansallisen tieteellisen yhdistyksen että yleisemminkin vuorovaikutuksen tutkimuksen kannalta vilkas ja antoisa.

Lopuksi haluan vielä kiittää vuosikirjan toimituskunnan jäseniä eli Malgorzata Lahtea, Jonna Koposta ja Riitta Vanhataloa sekä tietenkin lukuisaa anonyymien vertaisarvioijiemme joukkoa. Tarvitaan iso joukko ihmisiä ja aikamoinen määrä joustavaa yhteistyötä, että tällaisen julkaisun tuottaminen tulee mahdolliseksi.

Jyväskylässä marraskuussa 2015

Marko Siitonen, päätoimittaja 